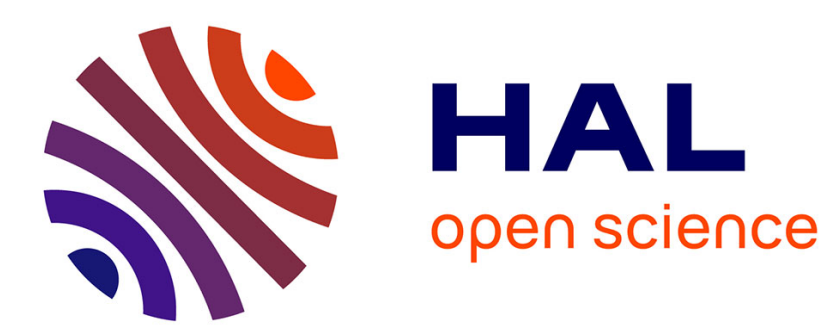

\title{
The space of social movements
}

Lilian Mathieu

\section{To cite this version:}

Lilian Mathieu. The space of social movements. Social Movement Studies, 2021, 20 (2), pp.193-207. 10.1080/14742837.2019.1630267 . halshs-03170246

\section{HAL Id: halshs-03170246 \\ https://shs.hal.science/halshs-03170246}

Submitted on 21 Dec 2021

HAL is a multi-disciplinary open access archive for the deposit and dissemination of scientific research documents, whether they are published or not. The documents may come from teaching and research institutions in France or abroad, or from public or private research centers.
L'archive ouverte pluridisciplinaire HAL, est destinée au dépôt et à la diffusion de documents scientifiques de niveau recherche, publiés ou non, émanant des établissements d'enseignement et de recherche français ou étrangers, des laboratoires publics ou privés. 


\title{
The Space of Social Movements
}

\author{
Lilian Mathieu (CNRS-ENS de Lyon)
}

Abstract: The article defines the concept of space of social movements, that describes the relatively autonomous microcosm of practice and meaning in which contentious mobilizations are linked by various relations of interdependence (e.g. inspiration, alliance, competition and conflict). By socially locating protest activities, the concept helps to understand the internal dynamics of the relationships between multiple movements and the relations the space of social movements maintains with other microcosms, such as the political and trade union fields. It also helps to analyze the practical aspects of contentious activities, as acting in the space of social movements requires from its members the control of some knowledge and skills that are acquired during a specific socialization process. The presentation of the concept is based on the analysis of French social movements from 1968 to 2010, and introduces a discussion of some of the main concepts of sociology of collective protest and of social differentiation, and especially Bourdieu's field theory.

Keywords: Contentious skills - Field - Interdependence - Protest practice - Politics Socialization

Correspondence Address: CNRS-Centre Max Weber, ENS de Lyon, 15 parvis Descartes, 69007 Lyon - France

lilian.mathieu@ens-lyon.fr

Lilian Mathieu is Senior Researcher in Sociology in the French National Center for Scientific Research (CNRS) and a member of the Centre Max Weber in the École normale supérieure in Lyon. His work mainly focuses on various social movements such as the May 68 revolt, migrant issues, feminism, Aids and prostitutes' rights campaigns, the alterglobalization movement, trade unions, artists' mobilizations, radical right groups or moral crusades. He has published several books, including Mobilisations de prostituées (2001), La Démocratie protestataire (2011), L'Espace des mouvements sociaux (2012), and La Fin du tapin. Sociologie de la croisade pour l'abolition de la prostitution (2014). His publications in English include "The Spatial Dynamics of the May 1968 Demonstrations" (Mobilization, 2008) and the chapter "Art and social movements" in the Wiley-Blackwell Companion to Social Movements (2018).

Acknowledgements: My thanks to the participants to the Montreal workshop on the context of contention (and especially to Laure Bereni) and to the New York Protest and politics workshop for their helpful comments on a earlier draft of this article. 


\section{The Space of social movements}

7970 words

Contemporary societies experience many social conflicts that are boosted by various organizations or groups, and that intend to defend different causes (e.g. feminism, peace, LGBT rights, workers' interests, access to housing, health, welfare or education, animal protection, and so on). They offer scholars the opportunity to produce numerous and substantial case studies, but difficulties appear when one aims to understand contentious activity as a whole, and to identify its peculiarities compared to other forms of public participation. What is needed is an account of the interdependence between different mobilizations, as contemporary movements simultaneously focus on specific stakes and are closely linked to one another by various relations such as inspiration, coalition, competition or conflict.

The purpose of this article is mainly theoretical, as its ambition is to provide a framework that puts this interdependence at the core of protest analysis and makes it a heuristic way to understand movement dynamics that are directly dependent from or connected to it. Its main hypothesis is that protest develops in a relatively autonomous microcosm that I call the space of social movements. Situating social movements within this microcosm, and the space of social movements within the whole social world, helps to identify how movements develop in interaction with each other within their own space, but also how protest action is interdependent with other microcosms. As such, the framework aims to articulate a structural dimension - the peculiar situation of movement activity within a differentiated social world — with a more individual one - that focuses on the dispositions that incline individuals to engage in contentious practice. Such a framework owes an obvious debt to Bourdieu's theory of fields, but also undertakes a critical reconsideration of its legacy while referring to other analytical traditions.

The elaboration of this framework is based on the analysis of various French social movements of the last decades. Thus I have studied the 1968 revolt of students and workers, the so-called "new social movements" of the 1970s, movements in defense of undocumented migrants, the feminist movement, the mobilization against Aids, the 1995 conflict against the 
reform of social insurance, conservative and extreme right groups, the protest of the unemployed, the crusade for the abolition of prostitution, and the alter-globalization movement, with various methods such as police archive, media data, interviews with leaders and constituents, and direct observation of protest activities. It is the study of all these movements that allowed me to identify their similarities, interactions and interdependence relations, and drove me to the formalization of the concept of the space of social movements. However, the fact that the elaboration of the framework is based on French cases raises questions about its application to other contexts, that will be addressed in the conclusion.

\section{Social movements as a microcosm}

Studying the space of social movements relies on the observation that modern societies are complex, i.e. differentiated between various microcosms that are relatively autonomous one from another and that are structured by specific logics. Social differentiation has been theorized by authors such as Elias (2001), Bourdieu (2000), Luhmann (1982), Becker (1983), and Dobry (1986) who have variously conceptualized these microcosms as configurations, fields, systems or sectors, and have stressed some of their peculiarities such as interdependence that links components of a configuration (Elias), structural homology between fields (Bourdieu), self-reference (Luhmann), conventions (Becker), or variations in the objectivity or the fluidity of sectors (Dobry $)^{1}$.

The fact that social movements constitute such a microcosm has also been stressed by many scholars, who have elaborated various concepts to designate and define it. Each one focuses on specific issues and enlightens peculiar dynamics of protest activity, and as such provided important insights for the elaboration of my own perspective.

Among the firsts, Curtis and Zurcher (1973) coined the concept of "multiorganizational field" to identify the network of organizations that join together during episodes of protest. The concept is helpful to identify the recruitment clusters of a single mobilization but is less relevant for the study of routine relations between organizations, and for the identification of what is specific in protest action. Such an issue, on the other hand, was taken into account by McCarthy and Zald (1977) when they coined the concept of a "social movement sector" that gathers the various "social movement industries" (SMIs) and, within them, the multiple "social movement organizations" (SMOs) within a given society.

\footnotetext{
${ }^{1}$ Except when explicitly refering to Bourdieu's field theory, I will use the general and neutral term "microcosm“ to designate the different worlds, systems, spheres or sectors that interact with the space of social movements.
} 
Their approach is based on an economic metaphor that gives the priority to competition (between SMIs and, within them, between SMOs) for resources such as time, money, activists, etc. This can appear limitative as relations between movements cannot be restricted to competition but also include inspiration, cooperation, or antagonism.

The concept of "social movement community" also aims to gather the multiple components of a given movement, for example at the local level-like when Staggenborg (1998) studied the feminist community in Bloomington, Indiana. It is useful to situate the recruitment clusters of a movement, that are often wider than the constituency of the organizations that lead it, and to identify its distinctive subculture. But, as such, it tends to homogenize movements' social basis and to neglect its internal differentiation or cleavages, and to portray a collection of unified but isolated social movement communities without apprehending their mutual links.

Twenty years ago, Giugni and Passy (1997) postulated the constitution in Western societies of a "social movement arena" that is parallel to the sphere of political parties and interest groups, by which citizens can express their claims to authorities but also inform the population about issues at stake. The idea that protest is a form of public participation that is distinct from institutional politics and that it obeys to specific logics is an important point that is shared by my own approach. I am however more cautious as I do not take the differentiation of protest from party politics as a given but I rather take into account that it can experience cyclical fluctuation. The same arena concept has recently been coined by Jasper (2015) but with a different meaning. According to him, arenas are structured bundles of rules and resources that allow or encourage certain kinds of interactions among players that engage in strategic action with the intent to pursue their own goals. Some arenas are settings where protest action, developed by players such as activists or SMOs, takes place but, as each arena is built by its own players (Jasper, 2015, p. 18), there does not exist a stable and unified social movement arena. Jasper's approach is more interactionist than structuralist, and tends to describe protest as a collection of scattered causes or isolated episodes of contention, while I focus on their mutual relations.

Even if Jasper intends to distance his model from Bourdieu's theory of fields, there are some similarities between the two, such as the peculiarities of the rules of the game that is played within each arena (or field), the hierarchy of positions hold by players that is based on the possession of relevant resources, or the fact that history shapes the interactions within each arena. Bourdieu's influence is more explicitly acknowledged by Fligstein and McAdam (2012) in their conceptualization of the "strategic action field", that they define as "a 
constructed mesolevel social order in which actors (who can be individuals or collective) are attuned to and interact with one another on the basis of shared (...) understandings about the purpose of the field, relations to others in the field (...), and the rules governing legitimate action in the field" (2012, p. 9). Each field is embedded in a broader environment composed of other strategic fields (the state among them) with whom it engages in different kinds of relations (2012, p. 59). Applying the framework to the case of the US civil rights movement attests its usefulness, as it shows how a series of transformations within proximate fields (economy, demography, or national and international politics) destabilized the field of racial politics in the South, resulting in the emergence of a new movement strategic field in the mid1950s, within which civil rights organizations mobilized in a coalition. Compared to Bourdieu's, Fligstein and McAdam's theory of fields appears limitative, as it restricts human action to strategy and lacks a theory of socialization (in Bourdieu's term, of habitus) in order to explain how the skills they grant social actors are acquired and why some of them are more skilled than others.

The legacy of Bourdieu's theoretical framework is more influential in France, where many sociologists and political scientists refer to his field concept to consider the specific microcosm that gathers social movements and to understand the bifurcations of activists' trajectories. In his study of the French leftist group Socialisme ou barbarie, Gottreaux (1997) speaks of a "radical political field" in order to study its connections to the intellectual field, as some of its former leaders converted their knowledge in Marxism in an academic career. Péchu (2007) talks about a "militant field" to analyze the trajectories of activists who engaged in the housing movement after some disappointment in leftist parties. Studying the French movements of the mid-1990s, Mauger (2003) suggested that there exists a "social movement field" within which one can identify four main components (trade-unionist, associative, intellectual and political).

The influence of Bourdieu has also become noticeable among some English-speaking scholars. Crossley (2003) stressed that belonging to the "contentious field" requires specific dispositions that define the "radical habitus", whereas Ray coined the concept of "protest fields", that she defines as "groups and networks that oppose those who have the power in the formal political arena and may or may not share the logic of politics in the larger political field, although they are constrained by it" (1999, p. 8). More recently, Ibrahim (2015) and Samuel (2017) have both approached alter-globalization as forming a field, within which movements compete and conflict about the best way to overturn capitalism or to produce new collective identities. They also both consider that a specific set of dispositions-e.g. a given 
habitus - is a precondition for developing some taste for protest or for challenging conformity. Husu (2013) appears more innovative as she mobilizes Bourdieu's work so as to bring back class in the study of the so-called identity movements, that has long neglected it; she more specifically shows how the class position of a movement's constituency influence its goals, ways of protesting and propensity to produce new norms and roles. She also suggests, once again mobilizing Bourdieu, that social movements are also symbolic struggles as they compete for the power to impose the legitimate vision of the social world.

The concept of a space of social movements shares many assumptions of these conceptualizations, and globally belongs to the same Bourdieusian tradition. But it also presents some differences - that will be detailed later in the article - regarding the autonomy and the structuration of the microcosm of social movements, that explain why I define it as a "space"2 rather than as a "field".

I define the space of social movements as a universe of practice and meaning that is relatively autonomous from other social microcosms (such as, among others, the political, trade union, media, religious or academic fields), and within which mobilizations (and the organizations and activists that lead them) are linked by various relations of interdependence ${ }^{3}$. In other words, I postulate that social movements develop within a relatively autonomous microcosm that is structured by its peculiar logics, and that its components are linked by relations of mutual dependence. These relations are fluctuant as they are sensitive to the evolutions of the context, and can vary from cooperation or coalition to competition or rivalry. This self-referential space is distinct from the other microcosms as it proposes to its members some specific stakes or rewards. It is also organized by specific temporalities, rules and schemes of perception that constrain members' practices, stances, anticipations, tactics and strategies. Full belonging to the space of social movements assumes that one controls the different skills inherent to its peculiar practice - especially the possession of a repertoire of contention - and knows the classification schemes of the various movements that are part of it; those classification schemes enable to mutually locate and evaluate rival or competitive members of the space. All these skills are acquired by socialization during an activist trajectory.

\footnotetext{
2 The spatial vocabulary is employed here as a metaphor and does not refer to the material space in which mobilizations take place (and to which many influential studies have been dedicated). It should be noted that even if it first referred to fields of forces in physical science, the Bourdieusian concept of field also owes its success to its metaphorical topographical connotations.

${ }^{3}$ Defining the elementary components of the space of social movements depends on the level of analysis. While, as will be shown in the last section, the individual level is relevant when one aims to study individual trajectories within the space, a meso- or macro-level study will be more productive when taking SMOs as units of analysis.
} 


\section{A specific space of interdependence}

As previously said, the interdependence that links social movements is never fixed, but it evolves according to the dynamics of the space. Some causes cyclically appear as a vanguard, as they seem to be more dynamic, potent, or legitimate - whereas, on the contrary, others appear more illegitimate, indefensible or tacky. Some can punctually constitute benchmarks that influence the strategies and anticipations of other movements. During the 1990s, different mobilizations have played such a role within the French space of social movements; their public resounding and their successes have proven influential over other movements that saw them as a source of inspiration. The giant condom on the Concorde square obelisk by Act Up in 1993, repeated requisitions of empty houses by Droit au logement in 1994, the strikes and demonstrations against the reform of social insurance in 1995, the occupation of a church in Paris by undocumented migrants in 1996, the movements of unemployed workers in $1997 \ldots$ are exemplary episodes that incited other movements to mobilize, eventually reproducing the repertoire of contention that had proven effective in promoting other grievances.

As such, the space of social movements is where a process of mutual evaluation takes place: the degree of mobilization of other movements, the fate of their initiatives, their tactical innovations or the original framing of their claims... are subjected to permanent evaluation, and offer cognitive indicators of a global context on which perceptions of what is possible, timely, or risky are grounded. This explains how protest cycles engage and develop: the success of a given movement encourages others to join the mobilization and to express their own grievances. In 1986 in France, for example, the victory of the student movement proved that the government was in a position of weakness and motivated railworkers to start a strike to express their own claims. Many authors have identified some effects of this mutual evaluation: McAdam (1983) stressed that tactical innovations diffuse among various movements as soon as they have proven effective, and Meyer and Whittier (1994) found that some movements stand as models for others that imitate their repertoires, frames or organizational devices that seem their key to victory. Failures play the same role, as they also give information about the context (especially about the balance of power against the antagonist, that is often but not always the state) and offer examples that must not be followed. Proust (2006) showed that the determination of the French entertainment workers (intermittents $d u$ spectacle) in 2003 was a product of the recent teachers' movement, whose 
failure was attributed to insufficient fighting spirit. It can be noted that this comprehensive and situational approach joins some of the criticisms that have been addressed to the concept of political opportunity structure (e.g. Goodwin \& Jasper, 2003). Political opportunities are not an objective given, such as institutional arrangements, but mostly play as situated perceptions of a context and interpretations of what can be done at a given moment.

It also should be noted that imitation does not exist only between movements that share the same ideologies or battlefields, but also between distant or even antagonist movements. Staggenborg (1991) showed, in her study of pro-choice and pro-life movements, that each one tried to adapt its action and organization to those of its antagonist in order to counter its initiatives, and that this process resulted in an isomorphism of both movements. The same phenomenon was observable in France during the demonstrations against the PACS (Pacte civil de solidarité, a first institutional recognition of same-sex couples) in 1999. Although they belonged to the religious right, the organizers claimed that the gay pride was their main source of inspiration as they tried to reproduce its youthful and joyful atmosphere, while reversing its signification. This inclination to imitation - that also needs some distinction - was a product of the antagonism between the religious conservative and the LGBT movements, that constrained them to engage in battlefields that had been opened by their adversary. After La Manif pour tous ("Demonstration for all"), the conservative movement against the law that opened marriage to same-sex couples, organized its first street demonstrations in 2012, the French LGBT movement had no choice but to demonstrate in many towns to support the law, to which La Manif pour tous answered back with an appeal to a national demonstration in Paris. It was important for each antagonist to gather more participants, and to appear as more determined, than the other. In such a situation, the conflict interdependence constrains each antagonist's action; they are not free to decide the rhythm and the stakes of their mobilization, as they are imposed by their adversary's initiatives, to which they have to fight back (Meyer \& Staggenborg, 1996).

Each position within the space of social movements is defined by some characteristics that can be considered, following Bourdieu, as specific kinds of capital. This capital can be the level of material resources, the number of members, the history of the group (that defines its legitimacy, e.g. when the group is well-known for its prestigious past and its glorious victories), its ideological, religious or philosophical inspiration, its social recruitment (regarding gender, age, level of cultural, symbolic, social or economic capital of members), etc. Like a field, the space of social movements is hierarchically structured as each of its positions is defined by an unequal volume of specific capital. Ideological affinities and 
similarities in social recruitment help to identify different poles within the space, that often play a decisive role in mobilization processes. Activists who concomitantly belong to different movements are helpful in forming coalitions, as they can play a broker role in connecting distinct groups or movements (McAdam, Tarrow \& Tilly, 2001).

Each position is also defined by its proximity to other microcosms, and especially by its degree of autonomy (or heteronomy) towards them. To say that the space of social movements has a relative autonomy is to say that the game that is played within it, and the stakes it offers, are different from those of other microcosms (social movements do not offer electoral positions, for example), but also that it is exposed to the influence that these other microcosms exert on it. Many SMOs are jealous of their independence from the political field $^{4}$, such as Attac or the Ligue des droits de l'homme whose statutes state that it is prohibited to refer to membership while running for election; if elected, an adherent must resign from all duties within the SMO in order to maintain a separation between the two microcosms. But other movements are well known for their close links with political parties (like SOS Racisme with the Socialist Party during the 1980s) or for their involvement in institutional politics (like anti-prostitution campaigns where one can find many "femocrats" Some organizations rely on private sources of subsidies and establish complex, and sometimes ambiguous, relations with the economy, like Act Up, whose funding by pharmaceutical companies exacerbated internal tensions. Others have close links with the intellectual field - like Attac, that gathers many academics within its scientific council—or with the religious field-like La Manif pour tous that is supported by the Catholic Church. All depend from media reports and have to adjust their actions and discourses to journalists' expectations and to establish connivance relations with them (Neveu, 1999).

Transformations in recruitment and in relations with other microcosms explain that the position one movement occupies within the space can significantly change. The renewal of generations of activists, the transformation of the internal balance of power between factions, the gain or loss in autonomy towards other microcosms, the fluctuation in the level of material resources... can substantially modify the position of a SMO. One can find an example in AC! (Agir ensemble contre le chomage or "Acting together against unemployment") that was created in 1993 by trade unionists who intended to counterbalance what they stigmatized as the indifference of the main French trade unions toward the problem of unemployment.

\footnotetext{
${ }^{4}$ As will be stressed later, the microcosm of politicians and parties that compete for institutional positions can be considered as a genuine field in Bourdieu's sense (Bourdieu 1999).

${ }^{5}$ Femocrats are defined by Banaszk (2010) as feminists who promote women's rights within the institutions.
} 
According to its founders, AC! should be a network linking various organizations (trade unions among them) and should claim for sharing employment (its slogan was then "working less for working all"). The position of AC! within the space of social movements was then close to the trade unionist field, but changed after its first initiative that was a national march against unemployment in 1994. The march was a tremendous success, as it gathered hundreds of unemployed people who joined AC!. But these new members did not share AC!'s first framing of the issue; many of them were people who had stopped working long ago and who did not want to go back to work. Instead, they claimed for a universal minimal allocation that would permit them to live decently without working. As they became predominant, the links with the trade unions field weakened and AC! became not much of a network but an independent organization.

\section{A relative and fluctuating autonomy}

The issue of autonomy is crucial for the comprehension of what I define as the space of social movements, and especially to understand its difference with the field concept. To evaluate the degree of autonomy — or its contrary, heteronomy — of that space, one needs to study the boundaries that separate it from other microcosms within the whole social world. The task to delimitate this line is not devoted to the sociologist, who has rather to follow Mauger's invitation to consider that "the absence of a definition of the 'social movement' is (...) a part of its definition" $(2004$, p. 33$)$, as the delimitation of the boundaries of the space is one of the stakes of the competition that opposes its various components.

Focusing on this competition is one of the main issues of any field analysis. But it seems that it is not possible to assign the status of a genuine field to the microcosm that social movements constitute, for different reasons. First of all, the space of social movements does not possess a degree of objectification, structuration and institutionalization sufficient to correspond to what Bourdieu considers as a field in his more rigorous definitions. On the internal side, the space of social movements appears as a too weakly unified sphere, in which the relations are too loosely objectified, to pretend to be a "real field". Contention develops in a microcosm that is informal and under-regulated, that is deprived of any authority that could establish uncontested hierarchies and verdicts in its internal competition (as elections do in the political field). The dispersion of many different causes, groups or organizations prevents it from becoming an objectified domain. If interdependence links the various components of the space of social movements, it is mostly a loose interdependence. 
Another reason to avoid the field concept stands in the important fluctuations of the autonomy of the space of social movements from other microcosms that are close to it. Those fluctuations prevent to follow Mauger when he says that "the social movement can be described as a sub-field within the political field" (2004, p. 37; see also Ray, 1999, p. 8). First, as it is analyzed by Bourdieu himself, the political field appears to be a too specific and narrow microcosm to include social movements. Extending Weber's approach of political beruf, Bourdieu defines the political field as a microcosm where professional politicians compete for the conquest or the conservation of positions of political power. Its autonomy is guaranteed by the specific kind of capital (nowadays rather an educational than an organizational capital) that is required to fulfil a politician career (Bourdieu 1999). Being a specialized and professionalized microcosm, the political field appears hermetically closed to ordinary citizens, social movements activists among them.

Second, being differentiated from the political field does not mean that the space of social movements is not strongly influenced by it—a situation Bourdieu would call heteronomy, i.e. the incapacity to sustain one's own rule due to external influence. As a matter of fact, autonomy and heteronomy are always relative and contextually fluctuant. Following Dobry (1986), I consider that the space of social movements can experience episodic variations in degree of autonomy that vary from peaks of autonomization (for example during tremendous contentious cycles) to quasi-disappearance (when there is a complete deflation of contentious activity).

A rapid overview of the evolution of contention in France from 1968 to the 2000s can illustrate this issue. May 1968 was a brutal and short phase of autonomization of contention, distinct from traditional political parties but in large part guided by students' revolutionary hopes. During the years to follow, the disappointment of these revolutionary ambitions has motivated young activists to quit their leftist groups and to reconvert in various social movements — some being the so-called "new social movements" (e.g. feminism, homosexual movements, ecology, or regionalism) — with more limited and easy-to-reach grievances. Many of these movements had closed mutual links, with numerous activists belonging to several of them at the same time or quitting one to join another. The high autonomy of the space of social movements from the political field weakened as it became clear that some goals could not be reached by disruptive means only, and because the main party of the left, the Socialist Party, stood as a "natural relay" of different grievances - the cancelation of a nuclear site in Plogoff and of a military camp in Larzac, the abolition of death penalty, the repeal of discriminatory laws against homosexuals, new civil rights for migrants, liberalization of radio 
broadcast, a fifth week of paid vacation, retirement at 60 years-old, etc. (Author, 2012). It became clear to many movement activists that voting for a socialist government was the only way to reach their ends; as a consequence, the end of the 1970s showed an alignment of their anticipations on the electoral calendar (the 1981 election, won by François Mitterrand who became the first left-wing president of the French $5^{\text {th }}$ Republic).

The deflation of contentious activity started before 1981, as many activistsespecially those who had started their activist career in 1968 - grew older and devoted more time for their family and their professional lives (Hirschman, 1982). But the political alternation also contributed to disarm social movements: main grievances achieved success, some movements leaders joined the cabinets of the new government, but mostly the deteriorated social and economic contexts offered less opportunity for protest. The space of social movements lost its autonomy from the political field and weakened as such, with little contentious activity during the 1980s (the migrants' children — "beurs"-and the 1986 student movements being the main exceptions). While the Socialist Party was taking over many movements, the collapse of the French extreme left since the mid-seventies also contributed to the weakening of the space of social movement, as extreme left groups were among the main clusters of movement activists. Another major cluster of French activism, that of the leftist Catholics ( "cathos de gauche"), waned at the same time, partly due to the conservative turn of the Catholic Church under the pontificate of John-Paul 2.

By the end of the 1980s, new organizations and protest episodes have paved the way for a reconstitution of the French space of social movements. This reconstitution focused on issues of precariousness and social exclusion. Act Up was founded in 1989 to claim for a real policy against Aids, but also to denounce the deterioration of the public health system and the fact that poor people were among the first victims of the epidemic. Posing as an emanation of the "gay community", Act Up boosted a remobilization of the LGBT movement, especially for the recognition of same-sex couples. Soon followed Droit au logement (DAL, "Right to housing") whose repertoire focused on the requisition of empty apartments to rehouse poor families, and by several important mobilizations: a massive feminist demonstration in defense of abortion in 1995, the church occupation movement by undocumented migrants in 1996, the mobilization of unemployed workers in 1997, the Strasbourg demonstration against the National Front the same year, etc.

The wide 1995 mobilization against a reform of social insurance that was decided by the right-wing government ("plan Juppé") blocked the whole country, as railworkers started a strike that stopped public transportation. This mobilization was a turning point, as the 
challengers engaged in a confrontation with the government, and won some concessions, without any support from the parties of the left, as many leaders of the Socialist Party supported the reform and the formerly powerful Communist Party was deliquescent. The mobilization proved that social movements were able to achieve success by their own means and without relying on the political field. The episode strengthened the self-reference of the space of social movements, i.e. the representation, shared by many activists, that it constitutes a distinct form of participation, that can significantly weigh on the political life despite it is apart from party politics. One of the main attestations of the consolidation of the selfreference of the space of social movements was the tribune "Nous sommes la gauche" ("We are the left") that Act Up and various movements published before the 1997 legislative elections, that defined social movements as different but equal to political parties in the incarnation of the "left".

The apparition of the alter-globalization movement in 1998 can be analyzed as an outcome of this reconstitution of the space of social movements, as it gathered many of these organizations and causes. The fact that the main French alter-globalization organization, Attac, ensured its independence towards political parties shows that the autonomy from the political field was an important issue for movements of the time. The discredit of political parties, the fear of being taken over and the ambition to maintain a form of action deprived of any personal (electoral) interest can explain that the space of social movements was wary of its autonomy. However, this autonomy was difficult to preserve, due to the persistent influence of the political field over the space of social movements: many movement activists are also party members, and movements often depend on the resources parties can afford them. The 2003 European social forum, for example, could not have been organized without the support of municipalities ran by the Communist Party and many movements are dependent from political or institutional support (Author, 2005). Even at its peak, the autonomy of the space of social movements is never complete.

The evolution of the relations between the space of social movements and the political field is also caused by the internal transformations of the latter, and especially by the conversion of the (then) main party of the left, the Socialist Party, to neoliberalism since the mid-1980 (Lefebvre \& Sawicki, 2006). As previously said, while it was in the opposition, the Socialist Party was able to catch many activists' hopes, and it satisfied many movements' claims during its first years in government, but disappointment was quick to follow and many of its members decided to quit and to develop a more concrete and disinterested kind of activism in SMOs (Agrikoliansky, 2000). This process was strengthened by the closure of the 
political field, as its dominant positions are monopolized by professional politicians (who have acquired political skills in elite institutions, such as Sciences-Po and the Ecole Nationale d'Administration) at the expense of grassroots members who have more connections with movements. From this point of view, the autonomization of the space of social movements is also the result of another autonomization — or closure-, that of the political field.

\section{Specific contentious skills}

So far, I have mainly focused on the "structural" dimensions of the space of social movements, as its internal structuration and its relations with other microcosms have remained at the core of the presentation. But the concept also aims to enlighten the subjective (i.e. what refers to the cognitive representations and perceptions of individual agents) and the pragmatic (i.e. what relates to the concrete conditions of action accomplishment) dimensions of contentious practice. The space of social movements can be considered as the site where a set of cognitive and practical skills, that are necessary for protest, are acquired and displayed. With such a framework, one can try to coordinate the level of "structure" and of "action" (Sewell, 1992), as well as to coordinate the "objective" and "subjective" dimensions of social reality (Berger \& Luckmann, 1966).

Defining the space of social movements as a distinct universe of practice and meaning supposes that those who belong to it, or who intend to penetrate in it, have at their disposal a set of knowledge and skills that are inherent to the practice of collective contention. In other words, to engage in a protest, and the achievement of the various activities by which it exists (e.g. writing leaflets, negotiating the path of a demonstration, explaining the movement's grievances to the media, heading a public meeting, recruiting new sympathizers, among others), needs the possession of practical skills. Those skills are actualized in situation and seem elusive as they are more often not acquired by formal and explicit learning. Most of these skills have been informally and progressively acquired during and by the participation to protest action - sometimes along an activist career in various and successive social movements.

Cognitive skills are equal in importance to practical ones. They consist in knowledge and schemes of perception that enable activists to find their way in the space of social movements, with the control of the specific language and classification criteria that enable to distinguish between traditions or currents (e.g. "anarchist", "leftist catholic", "vegan", "radical feminist", and so on). Knowing and controlling these schemes of perception inform 
and nourish the practice of protest, especially when one needs to anticipate and to counter the action some competitor, antagonist or partner is expected to take during an episode of contention. These schemes of perception are also grounded in precedents, in the light of which the present situation can be evaluated (Sewell \& McAdam, 2001). During uncertain contentious episodes, activists try to define a strategy by relying on previous similar events, like in 2003, when the protesters against the reform of the public retirement system expected that the railworkers, whose strike was decisive in 1995, would join the mobilization. The fact that they finally decided not to join was then experienced as a disappointment that negatively affected protesters' determination.

It would be impossible to give a complete list of the many competencies and knowledge that can be helpful for protest, but it is possible to suggest some of them. This is also an opportunity to consider from a pragmatic perspective some of the more classic themes of social movement analysis. This is especially the case of Tilly's (2004) repertoires of protest, that mostly exist as experiences of previous contentious actions that constrain present calculations, definitions of situations and anticipations, and that nourish protesters' practical dilemmas (Dobry, 1990). To have the practical control of different ways to publicly express grievances, knowing the specific advantages, defaults and risks of each, and, on the basis of this knowledge, being able to choose the protest action that is the more suited to the movement's goal and resources, to the balance of power and to the context, is a skill that is crucial for mobilization success.

Those skills and knowledge are not a given, but are the product of a specific socialization process that explains inequalities between groups or individuals. Some movements - and especially poor people's movements - show low degrees of protest skills and knowledge. As a consequence, their attempts to mobilize are often short-lived, invisible or appear as illegitimate: as in Becker's art worlds, protest is an activity ruled by some conventions (Becker 1983). Such disadvantaged groups need to establish alliances with more privileged ones that can be considered as protest virtuosos. This was the case in 1975 when prostitutes in Lyon intended to mobilize against police harassment; after a first autonomous attempt to publicly demonstrate that was a complete failure, they established an alliance with sympathizers from the left-wing of the Catholic church, who advised them to occupy a church — an action that had already proved successful in the migrants' movement (Siméant 1998). The same process can be identified in the undocumented migrants' movement (with the decisive support of French activists) and in the 1997 mobilization of unemployed workers (that benefited from the support of trade unionists). Such skilled supporters — or conscience 
constituents, as McCarthy and Zald (1977) call them - accomplish what can be considered as a cooptation of excluded groups within the space of social movements.

These inequalities in skills and knowledge help to explain why individuals or groups who have "good reasons" to protest against their unfair condition more often stay politically passive. They can be explained by differences in social trajectories, and especially by the experience (or its lack thereof) of some socialization sites such as family, school and work ${ }^{6}$. Having been raised in a family whose members already have political interests and practices (when parents talk politics at home or are trade unionists or bring their children to demonstrations, for example), being a member of youth groups (such as scouts) or of a student organization, working with unionized colleagues... are predictive of an inclination to collective protest. Matonti and Poupeau (2004) have coined the concept of "activist capital" (capital militant) to name what I consider as protest skills and knowledge. This concept is helpful to stress that there can be inequalities in the possession of this capital. Its economic metaphor is helpful to stress that there are exchange rates when one wants to convert the activist capital s.he has accumulated in the space of social movements in another microcosm. Some movement leaders (e.g. José Bové or Emmanuelle Cosse) ${ }^{7}$ try to rely on their activist symbolic capital to reconvert in a political career, but there is always some speculation, and some risk, in such a strategy. They are often stigmatized in the space of social movements for diverting their movement's collective struggle for their sole personal interests. Once they have crossed the line between the microcosms of social movements and of political parties, it's impossible to go back - this being the limit of the economic metaphor of the activist capital that, contrary to money, can not be changed several times in another currency.

Little research has been conducted, since then, on how, concretely, protest skills and knowledge are learned. The space of social movements is one of the sites ${ }^{8}$ where many activists learn how to launch and develop a mobilization, with many trials and errors, but also with direct advices from older or seasoned comrades. Much knowledge is needed on how movement traditions are transmitted from one generation to another, on founding experiences (of police repression, of the treason of a coalition partner, of the excitement of collective

\footnotetext{
${ }^{6}$ The study of the concrete mechanisms by which individuals incorporate appetences, inclinations and competencies for protest has been conducted in Author (2012) in the case of young trade-unionists and of promigrant activists, mobilizing Lahire's (2010) approach to socialisation processes.

${ }^{7}$ José Bové was the spokesman of the Confédération paysanne (a farmer trade union) and Emmanuelle Cosse the president of Act Up; both became leaders of the Green party; Bové was elected as a European deputy and Cosse became the minister of Housing.

${ }^{8}$ It is not, of course, the only one. Many skills and knowledge that can be helpful for protest are learned somewhere else and before entering it, for example in school (e.g. how to write a leaflet) or in scout groups (e.g. how to lead a group of several people).
} 
fighting, etc.), on the supports of the learning process (leader autobiographies, documentaries or fictions on past mobilizations, etc.), on the content of this learning process (how to write a leaflet, how to call colleagues for strike, how to escape from police assault and to cure the effects of teargas, etc.) by which activist status and identity are built.

\section{Conclusion}

The space of social movement concept intends to approach protest action as a distinct microcosm whose dynamics are determined, on its internal side, by the interdependence relations that link social movements with one another and, on its external side, by its relations with other microcosms. In comparison with other close concepts, its main contribution is to articulate three levels of analysis within the same theoretical framework: the micro-level of the individual dispositions and skills that enable to protest practice; the meso-level of the mutual relations between movements; and the macro-level of the situation of the space of social movements within a differentiated social world.

However, the diffusion of the concept presents some difficulties that can be stressed in conclusion. The first one is that the framework has been elaborated on the basis of a study of contention in France, where the separation of protest from institutional politics is a very sensitive issue since the 1906 Amiens Charter that poses trade unions apart from party politics and that is still commonly invoked when a social movement fears to be taken over by politicians. Such a fear is not so acute in many other countries where relations between parties and movements are more inclusive, i.e. where the space of social movements is not as autonomous from the political field (and from other microcosms). If a space of social movements exists in France, it would be the purpose of further research to find if it exists elsewhere, and under what forms. The second difficulty is closely related to the former: the theoretical framework faces difficulties to analyze movements - such as the alterglobalization movement - that exceed the national borders. Theories of social differentiation have implicitly taken the nation state as their level of analysis but one needs to think about the possibility of transnational microcosms.

The third difficulty concerns the relations between the space of social movements and the trade unions field. The trade unions field, at least in France, is very institutionalized as the union status is defined by the law. At the same time, it exerts a strong influence on the space of social movements, notably due to the fact that many trade unionists are movement activists but also because trade unions often use a repertoire of protest they share with social 
movements. Some recent mobilizations related to work-e.g. in fast food restaurants (Abdelnour et al., 2009) — or to conditions of living — such as the 2018 yellow jacket protest-, during which a competition appeared between traditional trade unions and more informal movements, show that defining the frontiers between the two microcosms is a clear stake for their protagonists.

\section{References}

Abdelnour S., Collovald A., Mathieu L., Péroumal F., Perrin E. (2009), "Précarité et luttes collectives: renouvellement, refus de la délégation ou décalages d'expériences militantes?", Sociétés contemporaines, 74, 49-71.

Agrikoliansky E. (2002), La Ligue française des droits de l'homme et du citoyen depuis 1945, Paris, L'Harmattan.

Becker H.S. (1983), Art Worlds, Oakland, University of California Press.

Berger P.L., Luckmann T. (1966), The Social Construction of Reality, New York, Anchor. Bourdieu P. (2000), Propos sur le champ politique, Lyon, PUL.

Crossley N. (2003), "From Reproduction to Transformation. Social Movement Fields and the Radical Habitus", Theory, Culture \& Society, 20(6), 43-68.

Curtis R.L., Zurcher L.A. (1973), "Stable Resources of Protest Movements: The MultiOrganizational Field", Social Forces, 52 (1), 53-61.

Dobry M. (1986), Sociologie des crises politiques, Paris, Presses de Science-Po.

Dobry M. (1990), “Calcul, concurrence et gestion du sens", in P. Favre (Ed.), $L a$ Manifestation (pp. 357-386), Paris, Presses de Science-Po.

Elias N. (2001), The society of Individuals, London, Continuum.

Fligstein N., McAdam D. (2012), A Theory of Fields, Oxford, Oxford University Press.

Giugni M., Passy F. (1997), Histoire des mobilisations politiques en Suisse, Paris, L'Harmattan.

Goodwin J., Jasper J.M. (eds.) (2003), Rethinking Social Movements, Lanham, Rowman \& Littlefield. 
Gottraux Ph. (1997), “Socialisme ou barbarie”. Un engagement politique et intellectuel dans la France de l'après-guerre, Lausanne, Payot.

Hirschman A.O. (1982), Shifting Involvements, Princeton, Princeton University Press.

Husu H.-M. (2013), Social Movements and Bourdieu. Class, Embodiment and the Politics of Identity, $\mathrm{PhD}$. dissertation, University of Jyväskylä.

Ibrahim J. (2015), Bourdieu and Social Movements. Ideological Struggles in the British Anticapitalist Movement, Basingstoke, Palgrave.

Jasper J.M. (2015), “Introduction. Playing the game”, in J.M. Jasper \& J.W. Duyvendak (Eds.), Players and Arenas. The Interactive Dynamics of Protest (pp. 9-32). Amsterdam, Amsterdam University Press.

Lahire B. (2010), The Plural Actor, Oxford, Polity.

Lefebvre R., Sawicki F. (2006), La Société des socialistes, Bellecombe-en-Bauges, Le Croquant.

Luhmann N. (1982), The Differentiation of Society, New York, University of Columbia Press.

McAdam D. (1983), "Tactical Innovation and the Pace of Insurgency”, American

Sociological Review, 48, 735-754.

McAdam D., Tarrow S., Tilly C. (2001), Dynamics of Contention, Cambridge, Cambridge University Press.

McAdam D., Sewell W. (2001), "It's About Time: Temporality in the Study of Social Movements and Revolutions", in R. Aminzade et al., Silence and Voice in the Study of Contentious Politics (pp. 89-125), Cambridge, Cambridge University Press.

McCarthy J.D., Zald M.N. (1977), "Resource Mobilization and Social Movements: A Partial Theory”, American Journal of Sociology, 82(6), 1212-1241.

Matonti F., Poupeau F. (2004), "Le capital militant”, Actes de la recherche en sciences sociales, 155, 4-11.

Mauger G. (1994), “Gauchisme, contre-culture et néo-libéralisme : pour une histoire de la 'génération 68'”, in CURAPP, L'Identité politique (pp. 206-226), Paris, PUF.

Mauger G. (2003), "Pour une politique réflexive du mouvement social", in Cours-Salies P., Vakaloulis M. (dir.), Les mobilisations collectives : une controverse sociologique (pp. 33-42), Paris, PUF. 
Meyer D.S., Staggenborg S. (1996), "Movements, Countermovements, and the Structure of Political Opportunity", American Journal of Sociology, 101(6), 1628-1660.

Meyer D.S., Whittier N. (1994), “Social Movement Spillover”, Social Problems, 41(2), 277298.

Neveu E. (1999), “Médias, mouvements sociaux et espace public”, Réseaux, 98, 19-85.

Péchu C. (2007), Droit au logement. Genèse et sociologie d'une mobilisation, Paris, Dalloz.

Proust S. (2006), “Les luttes autour du régime de l'intermittence et leur radicalisation en 2003”, in J. Balasinski, L. Mathieu (Eds.), Art et contestation (pp. 103-120), Rennes, PUR.

Ray Raka (1999), Fields of Protest, Cambridge, Cambridge University Press.

Samuel C. (2017), Conform, Fail, Repeat. How Power Distorts Collective Action, Toronto, Between the Lines.

Sewell W. (1992), “A Theory of Structure: Duality, Agency, and Transformation”, American Journal of Sociology, 98(1), 1-29.

Siméant J. (1998), La Cause des sans-papiers, Paris, Presses de Sciences-Po.

Staggenborg S. (1991), The Pro-Choice Movement. Organization and Activism in the Abortion Conflict, Oxford, Oxford University Press.

Staggenborg S. (1998), "Social Movement Communities and Cycles of Protest: The emergence and Maintenance of a Local Women's Movement”, Social Problems, 45(2), 180203.

Tilly C. (2004), Social Movements, 1768-2004, Boulder, Paradigm. 